\title{
Assessment of Foot Shape in Adult Females of Bangalee and Chakma Ethnic Groups
}

Sharmista Bhattacharjee ${ }^{{ }^{*}}$

Md. Ashrafuzzaman ${ }^{2}$

Shraboni Chakraborty ${ }^{3}$

'Department of Anatomy Marine City Medical College

Chattogram, Bangladesh.

${ }^{2}$ Department of Anatomy Chattogram Medical College Chattogram, Bangladesh.

${ }^{3}$ Raozan Upazila Health Complex Chattogram, Bangladesh.
*Correspondence to:

\section{Dr. Sharmista Bhattacharie}

Assistant Professor

Department of Anatomy

Marine City Medical College

Chattogram, Bangladesh.

Mobile: +8801715501860

Email:sharmista201@gmail.com

Date of Submission : 18.10 .2019

Date of Acceptance ： 10.12 .2019

www.banglajol.info/index.php/CMOSHMCJ

\begin{abstract}
Background : Foot morphology differs among ethnic groups. Proper knowledge of population specific variations are necessary for industrial design and forensic investigations. The study was aimed to measure the foot and determine the foot shape of adult Bangalee and Chakma females to find out and compare any ethnic variation.

Materials and methods: The study was conducted on 200 Chakma and 200 Bangalee adult females. Foot length and foot breadth were measured by slide caliper. Foot index was calculated and foot shape was determined from foot index.

Results: Mean value for length, breadth and index of foot were significantly higher in Chakmas than Bangalees. Percentage of slender foot was higher in Bangalees and broad foot shape was found more in Chakmas. Most of the participants of these two groups have standard foot shape.
\end{abstract}

Conclusion: Bangalee and Chakma adult females showed differences in structural characteristics of foot which may be attributed to their ethnicity and environment.

Key words: Foot shape; Bangalees; Chakmas.

\section{INTRODUCTION}

Foot is a complex structure that consists of bones, muscles, ligaments and joints. Shape of the foot differs among individuals as a result of age, gender, ethnicity and environment ${ }^{1,2}$. Distribution of the internal foot structure serves as an indicator of ethnic identity, age and gender of a deceased person in forensic investigations. Assessment of foot structure and shape is required for proper designing of footwear prosthetics and orthotics ${ }^{1,3}$. Foot shape and function is affected by weight bearing, obesity and habitual use of footwear or barefoot walking. Deviation from normal shape causes mechanical imbalance that may lead to injury of foot $t^{4,5,6}$.

The Bangalees are the largest ethnic group of Bangladesh and they are of mixed ethnic origin. The Chakmas are the second largest ethnic group after the Bangalees. This Mongoloid ethnic group resides mainly in the Chattogram Hill Tracts where as the Bangalee population is distributed throughout the country ${ }^{7,8}$. There is limited foot morphometric data on the Chakma and the Bangalee females of Bangladesh at present despite its importance. So, the focus of the present study is to provide basic information regarding the foot shapes of the two ethnic groups and to find out any existing ethnic variation.

\section{MATERIALS AND METHODS}

This cross sectional and study included 200 Bangalee and 200 Chakma adult females of 18 to 44 years of age from Chattogram city. Anyone with a history of operation or deformity of lower limb, any genetic, endocrine or neurological disorders were excluded from the study. The selected subject was asked to stand with her heel together and to keep her back as straight as possible so that her heels, buttocks, 
shoulders touched the wall. The stature was then measured in centimeters with measuring tape ${ }^{4}$. Weight was measured with an analogue weighing machine. Then BMI was calculated as $\mathrm{kg} / \mathrm{m}^{2}$. If BMI was between 18.5 and 24.9 , each participant was measured for right and left feet. The data for the both feet were pooled for statistical analysis of foot variables. Foot Length (FL) was measured from the posterior prominence of the heel to the tip of the longest toe ${ }^{9}$. Foot Breadth (FB) was measured as the distance between the most medial point on the head of the first metatarsal to the most lateral point on the head of the fifth metatarsal ${ }^{9}$. A manual sliding caliper was used to measure all the foot dimensions. Foot Index (FI): FI was calculated for each individual by dividing the foot breadth by the foot length $\times 100^{9}$. Three types of foot shapes were determined according to the foot index.

i. Slender foot: FI* $<$ FI-SD

ii. Standard foot: FI-SD $<\mathrm{FI}^{*}<\mathrm{FI}+\mathrm{SD}$

iii. Broad foot: $\mathrm{FI}^{*}>\mathrm{FI}+\mathrm{SD}$

(FI*- Individual foot index, FI - Mean foot index, SD- Standard Deviation)

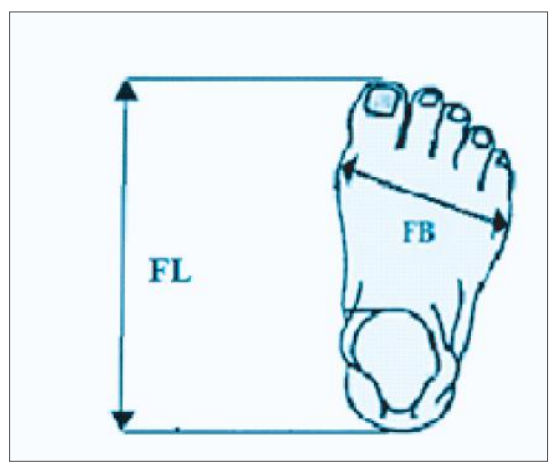

Figure 1 : Diagrammatic representation of selected foot measurements

(Source: Modified from Parham et $\mathrm{al}^{10}$ )

* FL-Foot Length, FB-Foot Breadth.

\section{RESULTS}

Table I : Comparison of demographic characteristics of Bangalee and Chakma ethnic groups

\begin{tabular}{lrlrrrl} 
Variable & \multicolumn{2}{c}{$\begin{array}{c}\text { Bangalee } \\
(\mathrm{n}=200)\end{array}$} & \multicolumn{2}{c}{$\begin{array}{c}\text { Chakma } \\
(\mathrm{n}=200)\end{array}$} & t value & $\begin{array}{l}\text { Significance } \\
(2 \text { tailed })\end{array}$ \\
& $\begin{array}{rrrrrr}\text { Mean } \\
\text { Agd }\end{array}$ & \multicolumn{1}{c}{ Mean } & \multicolumn{1}{c}{ SD } & & \\
Height $(\mathrm{cm})$ & 27.46 & 7.36 & 26.24 & 8.1 & 1.5765 & $0.1157 \mathrm{NS}$ \\
Weight $(\mathrm{Kg})$ & 50.69 & 6.08 & 49.97 & 6.78 & 1.1181 & $0.2642 \mathrm{NS}$ \\
BMI $\left(\mathrm{Kg} / \mathrm{m}^{2}\right)$ & 21.46 & 2.08 & 21.06 & 2.38 & 1.7897 & $0.0743 \mathrm{NS}$. \\
\hline
\end{tabular}

BMI- Body Mass Index, NS- Not Significant.

Table I showed the mean values and standard deviations of age, height, weight and BMI of both groups. In all the four categories, differences between means were not significant. So, the study groups were homogenous.
Table II : Comparison of foot variables between Bangalee and Chakma adult females

$\begin{array}{lllllllll}\text { Variables } & \begin{array}{l}\text { Bangalee } \\ (\mathrm{n}=200)\end{array} & \begin{array}{l}\text { Chakma } \\ (\mathrm{n}=200)\end{array} & \begin{array}{l}\text { Differences of SED } \\ \text { means between } \\ \text { study groups }\end{array} \\ & \text { Mean } & \text { SD } & \text { Mean } & \text { SD } & & & \begin{array}{l}\text { Significance } \\ (2 \text { tailed })\end{array} \\ \text { FL }(\mathrm{cm}) & 22.91 & 0.79 & 23.11 & 0.78 & -0.2021 & 0.078 & 2.5127 & 0.0124^{*} \\ \text { FB }(\mathrm{cm}) & 8.55 & 0.40 & 9.22 & 0.48 & -0.6708 & 0.044 & 15.1729 & 0.0001^{* * *} \\ \text { FI } & 37.35 & 1.92 & 39.94 & 2.23 & -2.59 & 0.208 & 12.4293 & 0.0001^{* * *} .\end{array}$

FL-Foot Length, FB-Foot Breadth, FI-Foot Index, SD-Standard Deviation, SED-Standard Error of Differences Between means:cm-centimeter.

- $(p>0.05)=$ Not significant, $(p<0.05)^{*}=$ Significant, $(p<$ $0.001)^{* * *}=$ Highly significant.

Table II presents the comparative analysis of foot variables between Bangalee and Chakma adult females. The foot length was higher among the Chakmas $(23.11 \pm 0.78 \mathrm{~cm})$ than the Bangalees $(22.91 \pm 0.79 \mathrm{~cm})$. The difference between the two groups was statistically significant. The mean foot breadth was $9.22 \pm 0.48 \mathrm{~cm}$ for the Chakmas and $8.55 \pm 0.4 \mathrm{~cm}$ for the Bangalees. The mean breadth was higher among the Chakmas and the difference was highly significant $(\mathrm{p}<0.001)$. Similarly, foot index value for Chakmas $(39.94 \pm 2.23)$ was higher than the Bangalees (37.35 \pm 1.92$)$ and the difference between means was highly significant $(\mathrm{p}<0.001)$.

Table III : Distribution and comparison of the participants by shapes of foot

$\begin{array}{lccll}\text { Foot Shape } & \text { Bangalee (\%) } & \text { Chakma (\%) } & \chi^{2} & \text { Significance } \\ \text { Slender } & 17.5 & 15.5 & 5.25 & 0.0724 \text { NS } \\ \text { Standard } & 68 & 67.5 & & \\ \text { Broad } & 14.5 & 17 & & \end{array}$

- $(\mathrm{p}>0.05)=$ Not significant $(\mathrm{NS})$

Table III shows the percentage distribution of Bangalee and Chakma females according to foot shape. The percentages of slender and standard foot was higher among the Bangalees (17.5\% and 68\%) than the Chakmas (15.5\% and 67.5\%). The Chakmas (17\%) had higher percentages of broad foot than the Bangalees (14.5\%). The differences in percent distribution of Bangalee and Chakma females at three foot shape categories were not statistically significant. So, Bangalee females do not differ significantly from their Chakma counterparts regarding foot shape.

\section{DISCUSSION}

Manna et al conducted a study on 100 Bangalee female in the age group of 25-35 years, residing at West Bengal in India ${ }^{11}$. The reported right foot length and breadth was $22.98 \pm 1.44 \mathrm{~cm}$ and $8.55 \pm 0.31 \mathrm{~cm}$ respectively. Their findings are similar to that of the Bangalee females of Bangladesh. Another study on 600 adult Punjabi women in the age rangeof 18-60 years found 
that right foot length and breadth were $23.14 \pm 1.11 \mathrm{~cm}$ and $8.65 \pm 0.45 \mathrm{~cm}^{2}$ respectively ${ }^{12}$. The mean foot length and breadth for Bangalees in the present study was less than that of Punjabi women. But foot index value for Punjabi women $(37.42 \pm 1.63$ $\mathrm{cm})$ was similar to that of the Bangalees. It suggested a similarity in proportion despite the differences in mean values of foot length and breadth.

Suakabkaew et al conducted a study on 250 Thai females of 2050 years of age and their right foot length and breadth were $23.17 \pm 0.99 \mathrm{~cm}$ and $9.3 \pm 0.5 \mathrm{~cm}^{13}$. It is similar to that of the Chakma females of the present study as both groups are Mongoloid in ethnicity. Xiong et al. worked on 24 Hong Kong Chinese women with mean age of $22.46 \pm 2.5$ years ${ }^{14}$. Their reported foot length and foot breadth were $23.24 \pm 0.86 \mathrm{~cm}$ and $9.03 \pm 0.48 \mathrm{~cm}$ respectively. Chakma females had smaller and broader foot than the Hong Kong Chinese. Shoe wearers such as Hong Kong Chinese women tend to have narrower feet than sandal wearers or barefoot walkers like the Chakmas ${ }^{6}$. Kouchi observed that the mean values for foot index in Japanese, Australian aborigine, French and Indonesian females were 41.0, $38.2,38.6$ and 40.8 respectively ${ }^{15}$. The foot index value for the Chakmas are more similar to that of the Japanese and Indonesian than the Australian aborigine and French.
According to the findings of the present study, the Chakma females have higher mean values for foot length, foot breadth and foot index than their Bangalee counterparts. The greater foot index in Chakmas indicates wider feet for a given foot length than the Bangalees. This finding is in agreement with kouchi who observed that Mongoloid populations tend to have a wider foot for foot length ${ }^{15}$. The Chakma females also have higher percentage of broad foot shape whereas the Bangalees have greater percentages of slender and standard foot shape. The larger dimensions of foot in Chakma females are suggestive of increased surface area as a result of genetic adaptation to temperature stress in the warmer climate of the Chattogram Hill Tracts ${ }^{16}$.

\section{CONCLUSION}

The Chakma females have larger dimensions of foot than their Bangalee counterparts which may be attributed to their ethnicity and environment. It is of great importance to identify the variations of foot morphological characteristics among different ethnic groups for the successful design of commercial products such as footwear, prosthetics and orthotics for specific ethnic group. The knowledge of population specific variations are also required in forensic investigations to establish ethnic identity.

\section{DISCLOSURE}

All the authors declared no competing interest. 


\section{REFERENCES}

1. Tomassoni D, Traini E, Amenta F. Gender and age related differences in foot morphology. Maturitus. 2014; 79: 421-427.

2. Wunderlich RE,Cavanagh PR. Gender differences in adult foot shape: implications for shoe design. Medicine and Science in Sports and Exercise. 2001;33(4):605-611.

3. Jervas E. Foot Anthropometry: A Forensic and Prosthetic Application. International Journal of Science and Research. 2015;4(6):738-746

4. Ahmed S, Akhter AB, Anwar S, Begum AA, Rahman K, Saha NC. Comparison of the Foot Height, Length, Breadth and Types between Santhals and Bangalees of Pirganj, Rangpur, Bangladesh. Bangladesh Journal of Anatomy. 2013;11(1):30-33.

5. Hills AP, Henning EM, McDonald M,Bar-Or O. Plantar pressure differences between obese and non-obese adults: A biomechanical analysis International journal of obesity and related metabolic disorders: Journal of the International Association for the Study of Obesity. 2001;25(11):1674-1679.

6. D'Aou^ t K., Patakyc T., De Clercqd D, Aertsad P. The effects of habitual footwear use: foot shape and function in native barefoot walkers. Footwear Science. 2009;1(2):81-94.

7. Wikipedia 2017. Bangladeshis. Available at: https://en.wikipedia.org/wiki/Bangladeshis.

8. Wikipedia 2017, Chakma people. Available at: https://en.wikipedia.org/wiki/Chakma_people.

9. Chiroma SM, Attah MO, Taiwo IO, Buba HS, Dibal NI, Jacks TW. Metric analysis of the foot of Yoruba students at the University of Maiduguri, Nigeria. IOSR Journal of Dental and Medical Sciences. 2015;14(8):63-67.

10. Parham KR, Gordon CC, Bensel CK. Anthropometry of the Foot and Lower Leg of US Army Soldiers: Fort Jackson, SC--1985 (No. NATICK/TR-92/028). Army Natick Research Development and Engineering Center Ma.1992:;1-332.

11. Manna I, Pradhan D, Ghosh, S, Kar, SK and Dhara P. A comparative study of foot dimension between adult male and female and evaluation of foot hazards due to using of footwear. Journal of physiological anthropology and applied human science. 2001; 20(4):241-246.

12. Pathak S, Pathak, RK. Foot Length, Foot Width and Foot Index of Adult Punjabi Women. Imperial Journal of Inter disciplinary Research. 2016;2(8):1367-1370.

13. Suakabkaew T, Ricngrojpitak S, Tiensuwarr, M. Stature Estimation from Foot Measurements in Thais. Proceedings of the Anatomy Association of Thailand. 2012:74-77.

14. Xiong S, Goonetilleke RS, Witana CP, Lee Au EY. Modelling foot height and foot shape-related dimensions. Ergonomics. 2008;51(8):12721289.

15. Kouchi M. Foot dimensions and foot shape: Differences due to growth, generation and ethnic origin. Anthropological Science. 1998;106:161188.

16. Katzmarzyk PT, Leonard WR. Climatic influences on human body size and proportions: Ecological adaptations and secular trends. American Journal of Physical Anthropology. 1998; 106(4):483-503. 